J. Dairy Sci. 97:1413-1426

http://dx.doi.org/10.3168/jds.2013-6982

(C) American Dairy Science Association ${ }^{\circledR}, 2014$.

\title{
Efficacy of oral potassium chloride administration in treating lactating dairy cows with experimentally induced hypokalemia, hypochloremia, and alkalemia
}

\author{
P. D. Constable, ${ }^{1}$ M. W. H. Hiew, S. Tinkler, and J. Townsend \\ Department of Veterinary Clinical Sciences, Purdue University, West Lafayette, IN 47907
}

\begin{abstract}
Hypokalemia occurs commonly in lactating dairy cows. The objectives of this study were to determine (1) whether a 24-h oral $\mathrm{KCl}$ dose of $0.4 \mathrm{~g} / \mathrm{kg}$ of body weight $(\mathrm{BW})$ was effective and safe in hypokalemic cattle; (2) whether potassium was best administered as 2 large doses or multiple smaller doses over a $24-\mathrm{h}$ period; and (3) the effect of oral $\mathrm{KCl}$ administration on plasma $\mathrm{Mg}$ concentration and urine $\mathrm{Mg}$ excretion in fasted lactating dairy cattle. Plasma $\mathrm{K}$ and $\mathrm{Cl}$ concentrations were decreased, and blood $\mathrm{pH}$ increased, in 15 lactating Holstein-Friesian cows by administering 2 intramuscular (i.m.) 10-mg injections of isoflupredone acetate $24 \mathrm{~h}$ apart followed by $2 \mathrm{i} . \mathrm{m}$. injections of furosemide $(1 \mathrm{mg} / \mathrm{kg}$ of BW $8 \mathrm{~h}$ apart and by decreasing feed intake. Cows were randomly assigned to 1 of 3 treatment groups with 5 cows/group: untreated control (group C); oral administration of $\mathrm{KCl}$ at $0.05 \mathrm{~g} / \mathrm{kg}$ of BW 8 times at 3-h intervals (group K3); and oral administration of $\mathrm{KCl}$ at $0.2 \mathrm{~g} / \mathrm{kg}$ of $\mathrm{BW}$ twice at $12-\mathrm{h}$ intervals (group K12). A 24-h KCl dose rate of $0.4 \mathrm{~g} / \mathrm{kg}$ of $\mathrm{BW}$ increased plasma and milk $\mathrm{K}$ concentration and plasma $\mathrm{Cl}$ concentration, and corrected the metabolic alkalosis and alkalemia, with no clinically significant difference between 2 large doses (group K12) or multiple small doses (group K3) of $\mathrm{KCl}$ over $24 \mathrm{~h}$. Oral $\mathrm{KCl}$ administration decreased peripheral fat mobilization in cattle with experimentally induced hypokalemia, as measured by changes in plasma nonesterified fatty acid concentration, and slightly augmented the fasting-induced decrease in plasma $\mathrm{Mg}$ concentration. Our findings support recommendations for a 24-h oral $\mathrm{KCl}$ dose of $0.4 \mathrm{~g} / \mathrm{kg}$ of $\mathrm{BW}$ for treating moderately hypokalemic cattle. Additional $\mathrm{Mg}$ may need to be administered to inappetant lactating dairy cattle being treated with oral $\mathrm{KCl}$ to minimize $\mathrm{K}$-induced decreases in magnesium absorption.
\end{abstract}

Received May 1, 2013.

Accepted October 3, 2013.

${ }^{1}$ Corresponding author: constabl@purdue.edu
Key words: potassium, hypochloremia, hypomagnesemia, alkalemia

\section{INTRODUCTION}

Hypokalemia occurs commonly in lactating dairy cows with left displaced abomasum (LDA), right displaced abomasum, abomasal volvulus, abomasal impaction, clinical mastitis, retained placenta, and hepatic lipidosis (Smith et al., 2001; Wittek et al., 2005; Kalaitzakis et al., 2010; Constable et al., 2013). The high prevalence of hypokalemia in sick lactating dairy cows is most likely due to a combination of decreased DMI, alkalemia due to sequestration of chloride in the gastrointestinal tract in cattle with LDA, right displaced abomasum, abomasal volvulus, or decreased abomasal emptying rate, hyperinsulinemia secondary to hyperglycemia, the obligatory loss of potassium in milk (1.4 g of $\mathrm{K} / \mathrm{L}$ of milk), sympathetic nervous system activation, aldosterone release in response to hypovolemia and the need for sodium retention, and decreased whole-body $\mathrm{K}$ stores due to the relatively low muscle mass in dairy cows (Grünberg et al., 2006; Constable et al., 2009, 2013). Whole-body depletion of $\mathrm{K}$ may be present in healthy dairy cattle immediately after calving, based on the results of $\mathrm{K}$ balance studies (Shalit et al., 1991), studies documenting decreased skeletal muscle $\mathrm{K}$ content at calving (Kowalczyk and Mayer, 1972), and decreased urine [K] immediately after calving (Hörügel and Fürll, 1998). Hypokalemia is most commonly defined as serum or plasma $[\mathrm{K}]<3.9$ $\mathrm{mEq} / \mathrm{L}$ in adult cattle (Radostits et al., 2007), although some studies have used a value $<3.9 \mathrm{mEq} / \mathrm{L}$ for serum or plasma $[\mathrm{K}]$ to define hypokalemia (Constable et al., 1991, 2013).

Oral potassium administration is the method of choice for treating lactating dairy cattle with hypokalemia. Oral administration of $\mathrm{KCl}$ appears to provide the optimal salt formulation for treating cattle with hypokalemia in that $\mathrm{K}$ is needed in cattle with wholebody $\mathrm{K}$ depletion, and chloride is needed in cattle with alkalemia and $\mathrm{pH}$-induced compartmental shift of $\mathrm{K}$ to 
the intracellular space (Constable et al., 2013). Current treatment recommendations are to administer 30 to 60 $\mathrm{g}$ of feed-grade $\mathrm{KCl}$ orally twice at a 12 -h interval to inappetant dairy cattle with mild to moderate hypokalemia, thereby providing a total 24 -h dose of 60 to $120 \mathrm{~g}$ of $\mathrm{KCl}$ (Constable, 2003). The $\mathrm{KCl}$ is administered by use of a balling gun and gelatin boluses or by ororuminal intubation. The treatment recommendation for dairy cattle with severe hypokalemia $(<2.5 \mathrm{mEq} / \mathrm{L})$ is $120 \mathrm{~g}$ of $\mathrm{KCl}$ orally, followed by two $60-\mathrm{g} \mathrm{KCl}$ oral treatments at 8-h intervals, for a total 24 -h treatment of approximately $240 \mathrm{~g}$ of $\mathrm{KCl}$ (Sattler et al., 1998; Constable, 2003); this dose is equivalent to a daily $\mathrm{KCl}$ dose of $0.4 \mathrm{~g} / \mathrm{kg}$ of BW for a $600-\mathrm{kg}$ dairy cow. Total daily oral doses of $\mathrm{KCl}$ exceeding $0.4 \mathrm{~g} / \mathrm{kg}$ of $\mathrm{BW}$ are not currently recommended except in cattle with profound hypokalemia because they have the potential to result in diarrhea, excessive salivation, muscular tremors of the legs, labored breathing, convulsions, and death (Dennis and Harbaugh, 1948; Peek et al., 2000; NRC, 2001; Constable, 2003).

We were interested in 3 questions related to the treatment of hypokalemia in lactating dairy cattle. The first was to verify whether a 24 -h oral $\mathrm{KCl}$ dose of $0.4 \mathrm{~g} / \mathrm{kg}$ of BW was effective and safe. The second was to determine whether $\mathrm{KCl}$ was best administered as 2 large doses or multiple smaller doses over a $24-\mathrm{h}$ period. Two large doses over $24 \mathrm{~h}$ may be preferable because oral administration of $\mathrm{KCl}$ results in a dosedependent increase in rumen $[\mathrm{K}]$ and, consequently, a dose-dependent increase in the number of moles of potassium absorbed per unit time (Scott, 1967). However, a large $\mathrm{K}$ dose may activate a gut or hepato-portal sensor that detects $\mathrm{K}$ intake and sends a signal to the kidney to increase $\mathrm{K}$ excretion in response to increased $\mathrm{K}$ ingestion (Greenlee et al., 2009), thereby resulting in less absorbed $\mathrm{K}$ being retained. The third issue was to determine the effect of $\mathrm{KCl}$ administration on plasma $\mathrm{Mg}$ concentration and urine $\mathrm{Mg}$ excretion. This was of interest because increasing dietary $\mathrm{K}$ intake decreases Mg absorption across the rumen epithelium (LeonhardMarek et al., 2010) and apparent Mg digestibility (Weiss, 2004). Oral $\mathrm{KCl}$ administration therefore has the potential to decrease plasma $\mathrm{Mg}$ concentration. A randomized, controlled study in lactating dairy cows with experimentally induced hypokalemia and decreased feed intake was therefore undertaken to explore the 3 issues of interest related to oral $\mathrm{KCl}$ treatment. The experimental model was designed to provide a clinically relevant model of hypokalemia, hypochloremia, metabolic alkalosis, alkalemia, decreased feed intake, whole-body $\mathrm{K}$ depletion, and mild dehydration in sick lactating dairy cows.

\section{MATERIALS AND METHODS}

All methods were approved by the Purdue University Institutional Animal Care and Use Committee.

\section{Animals, Housing, and Feeding}

Eighteen pluriparous Holstein-Friesian cows were monitored after parturition and acclimated to a tiestall at the Purdue Dairy Research and Education Center (West Lafayette, IN). All cows were healthy based on the results of routine physical examination and were enrolled into the study at 7 to 14 DIM. Cows were fed a balanced TMR that met the requirements of early lactating cows as recommended by the National Research Council (NRC, 2001). The ration was fed once daily between 0800 and $1000 \mathrm{~h}$ and was based on corn silage, alfalfa haylage, and high-moisture corn (typical analysis: CP, 17.3\%; ADF, 20.1\%; NDF, 30.2\%; Ca, $0.97 \% ; \mathrm{P}, 0.37 \% ; \mathrm{Mg}, 0.34 \% ; \mathrm{K}, 1.42 \%$ in $\mathrm{DM}$ with an energy density of 1.72 Mcal of $\mathrm{NE}_{\mathrm{L}} / \mathrm{kg}$ of $\mathrm{DM}$ ). Amounts of TMR fed and refused on a wet weight basis were recorded daily during the study period. Water was available ad libitum throughout the study. Cows were milked twice daily after calving between 0730 and 0900 $\mathrm{h}$ and between 1600 and $1930 \mathrm{~h}$ in a double-sided herringbone milking parlor. Milk weights were recorded for every milking.

Physical examination and sampling when done on a daily basis occurred between 0800 and $1200 \mathrm{~h}$ and before administration of any treatments. Urine samples were obtained daily by perineal stimulation and free catch of a midstream voided sample, except on d 4 when urine samples were collected via a Foley catheter in the bladder. Respiratory rate was determined by visual inspection of thoracic excursions for $30 \mathrm{~s}$. Heart rate was determined by thoracic auscultation for $30 \mathrm{~s}$. Cardiac rhythm was monitored daily, except on d 2, using a base-apex lead system connected to an electrocardiograph (PageWriter Xli, Hewlett-Packard, Boise, ID), which recorded a standard 10-s rhythm strip at $25 \mathrm{~mm} / \mathrm{s}$ and $1 \mathrm{~cm}=1 \mathrm{mV}$. Cattle were kept in a standing position during recording. Rectal temperature was determined by placing an electronic thermometer into the rectum for at least $30 \mathrm{~s}$. Rumen contraction rate was determined by auscultation of the left dorsal paralumbar fossa for $3 \mathrm{~min}$. Cows were weighed using a calibrated digital large-animal scale immediately after the morning milking on $\mathrm{d} 1,4$, and 7 .

\section{Experimental Method}

Cows were administered 2 i.m. 10-mg injections of isoflupredone acetate (9-fluoro-prednisolone acetate; 
Predef-2X, Pfizer Animal Health, Kalamazoo MI) 24 $\mathrm{h}$ apart on the morning of $\mathrm{d} 1$ and $\mathrm{d} 2$, immediately after physical examination and obtaining samples. The hypokalemic effect of isoflupredone acetate occurs because the mineralocorticoid activity of isoflupredone enhances renal and gastrointestinal (salivary and colonic) losses of potassium. Isoflupredone-induced hypokalemia reaches its nadir of approximately 60 to $70 \%$ of the normal value by $72 \mathrm{~h}$ after the first of two 10-mg injections (Neff et al., 1960; Coffer et al., 2006), equivalent to d 4 of the study reported here.

The amount of TMR fed on d 3 was decreased to $50 \%$ of that recorded on $d 2$. Feed reduction decreases the rumen potassium concentration and total potassium mass available in the forestomach for absorption and decreases plasma potassium concentration (Holtenius and Dahlborn, 1990).

An i.m. injection of furosemide $(1 \mathrm{mg} / \mathrm{kg}$ of $\mathrm{BW})$ was administered on the morning of d 3 immediately after physical examination and obtaining samples. A second furosemide injection $(1 \mathrm{mg} / \mathrm{kg}$ of BW, i.m.) was administered on the afternoon of $\mathrm{d} 3$ approximately 8 $\mathrm{h}$ after the first furosemide injection. Furosemide is a potent dose-dependent loop diuretic that inhibits the renal reabsorption of sodium, potassium, and chloride by binding to and inhibiting the activity of the $\mathrm{Na}^{+} /$ $\mathrm{K}^{+} / 2 \mathrm{Cl}^{-}$cotransporter, thereby inducing a hypochloremic, hypokalemic, metabolic alkalosis (Vestweber et al., 1989).

A jugular venous catheter was placed in the afternoon on $\mathrm{d} 3$. The skin over the right jugular vein was clipped and aseptically prepared. One milliliter of lidocaine was injected under the skin over the jugular vein and the skin incised ( $1 \mathrm{~cm}$ incision) with a scalpel blade to assist in catheter placement. A 16-gauge, 8-cm-long catheter (Angiocath, Becton Dickinson, Franklin Lakes, NJ) was placed in the jugular vein, an extension set (T-Port extension set ET04TSR, Braun, Bethlehem, $\mathrm{PA})$ attached to the catheter, and the catheter and extension set secured to the neck. After placement, the catheter was flushed every 8 to $16 \mathrm{~h}$ with heparinized $0.9 \% \mathrm{NaCl}$ solution (40 $\mathrm{U}$ of heparin $/ \mathrm{mL}$ ). The jugular venous catheter was removed at approximately $72 \mathrm{~h}$ after placement or earlier if it became nonfunctional or clinical signs of thrombophlebitis were evident.

A Foley catheter (30 French, 16" $\times 30 \mathrm{~mL}$ balloon; Jorgensen Laboratories, Loveland, CO) was placed aseptically into the bladder on the morning of $\mathrm{d} 4$ and fixed in position by inflating the balloon to approximately 60 to $65 \mathrm{~mL}$ with water. A high balloon inflation volume was used because the recommended inflation volume of $30 \mathrm{~mL}$ resulted in some catheters being extruded from the bladder. Silicon tubing was attached to the Foley catheter and routed to a 4-L collection jar for timed volumetric collection of urine samples. Tubing was disconnected at milking time on $\mathrm{d} 4$.

\section{Treatment}

Treatment was administered on the morning of $\mathrm{d} 4$ at least $1 \mathrm{~h}$ after placement of the Foley catheter. This was approximately $16 \mathrm{~h}$ after the last furosemide injection and $24 \mathrm{~h}$ after TMR intake had been decreased by $50 \%$. Fasting was then started for $24 \mathrm{~h}$ by removing all feed accessible to the cow; this provided a total duration of $48 \mathrm{~h}$ of reduced feed intake to facilitate detection of potassium changes due to treatment. The calculated dose of KCl (Sigma-Aldrich, St. Louis MO) was placed into gelatin capsules (Torpac Inc., Fairfield, NJ) and administered to the caudal aspect of the buccal cavity by a metal balling gun (Torpac Inc.).

Cows were randomly assigned to 1 of 3 treatment groups using a random number generator (Excel, Microsoft Corp., Redmond, WA). Randomization occurred in blocks of 3 to account for any seasonal effects during the study, which took place during September and October. The 3 groups, with 6 cows/group, were (1) control $(\mathbf{C})$ : insertion of the balling gun into the buccal cavity twice at 12-h intervals; (2) oral administration of $\mathrm{KCl}$ at $0.05 \mathrm{~g} / \mathrm{kg}$ of BW 8 times at 3-h intervals (group K3; total $24 \mathrm{~h}$ dose of $\mathrm{KCl}=0.4 \mathrm{~g} / \mathrm{kg}$ of $\mathrm{BW}$ ); and (3) oral administration of $\mathrm{KCl}$ at $0.2 \mathrm{~g} / \mathrm{kg}$ of $\mathrm{BW}$ twice at 12-h intervals (group K12; total $24 \mathrm{~h}$ dose of $\mathrm{KCl}$ $=0.4 \mathrm{~g} / \mathrm{kg}$ of $\mathrm{BW})$. The $24-\mathrm{h}$ dose rate for $\mathrm{KCl}$ was based on published recommendations (Constable, 2003; Constable et al., 2013), with K3 representing multiple smaller bolus doses and K12 representing 2 larger bolus doses. Treatment was administered at approximately 1000 and $2200 \mathrm{~h}$ (groups C and K12) and 1000, 1300, and $1600 \mathrm{~h}$ (immediately before the afternoon milking), 1900, 2200, 0100, 0400, and $0700 \mathrm{~h}$ (immediately before the morning milking; group K3). Cows were permitted ad libitum access to the TMR after the 24-h fast (d 5, 6 , and 7 ). Cows were followed for $96 \mathrm{~h}$ after the start of treatment (d 4, 5, 6, and 7).

\section{Jugular Venous Blood Sampling and Analysis}

Venous blood samples for plasma biochemical analysis were obtained on the morning of $\mathrm{d} 1,4,5,6$, and 7 , and at $0.5,1,2,4,6,12$, and $18 \mathrm{~h}$ after the start of treatment on d 4 . Blood samples were obtained by venipuncture of the left or right jugular vein using an 18-gauge needle ( 1 and 7 ) or via the catheter in the right jugular vein (d 4, 5, and 6). Jugular venous blood for plasma biochemical analysis was collected using a 4.5-mL syringe containing lithium heparin (Monovette; Sarstedt, Newton, NC) to minimize the effect of collec- 
tion-induced hemolysis on increasing plasma potassium concentration (Schulze, 2009). Syringes containing blood were maintained vertically at room temperature because placing heparinized blood into ice water depresses cellular Na-K ATPase activity and results in the movement of intracellular potassium into plasma (Stankovic and Smith, 2004). Syringes were centrifuged within 30 min of collection at $1,000 \times g$ for 10 to 15 min at room temperature and the plasma harvested and stored at $-75^{\circ} \mathrm{C}$ until analyzed (Stankovic and Smith, 2004). Biochemical analysis was performed on samples thawed at room temperature using an automated analyzer (Hitachi 911, Roche Diagnostics, Basel, Switzerland) to determine the plasma concentrations of $\mathrm{Na}$ (ion-selective potentiometry), K (ion-selective potentiometry), $\mathrm{Cl}$ (ion-selective potentiometry), total Ca (arsenazo dye binding), Mg (xylidyl blue), P (ammonium molybdate), creatinine (picric acid), and total protein (biuret). The change in plasma volume, relative to that on $\mathrm{d} 1$, was calculated as a percentage change using measured plasma protein concentrations as described elsewhere (Constable et al., 2009). The metabolic status on $\mathrm{d} 1,4,5,6$, and 7 was evaluated by measuring the plasma concentrations of NEFA [acyl-CoA synthetase-acyl-CoA oxidase (ACS-ACOD) method], BHBA (3-hydroxybutyrate dehydrogenase), and glucose (hexokinase) using an automated analyzer (Hitachi 911, Roche Diagnostics) and the same plasma sample that had been analyzed for electrolyte and total protein concentrations.

Venous blood samples for blood $\mathrm{pH}$ and gas analysis were obtained in the morning on d 1, 4, 5, 6, and 7 . Blood samples were obtained by anaerobic venipuncture of the jugular vein using an 18-gauge needle (d 1 and 7 ) or via the catheter in the jugular vein ( $\mathrm{d} 4$, 5 , and 6 ) into a 3 -mL polypropylene syringe containing lyophilized lithium heparin (3 mL Portex syringe, Smiths Medical ASD Inc., Keene, NH). Syringes were maintained at room temperature before being analyzed within $2 \mathrm{~h}$ using a blood gas analyzer (ABL5 pH and blood gas analyzer, Radiometer, Copenhagen, Denmark). Measured values from blood gas analysis $(\mathrm{pH}$, partial pressure of $\mathrm{CO}_{2}\left(\mathbf{p} \mathbf{C O}_{2}\right)$ and partial pressure of $\mathrm{O}_{2}\left(\mathbf{p O}_{2}\right)$ ] were corrected for rectal temperature using standard equations (CLSI, 2009). The plasma concentration of bicarbonate $\left(\boldsymbol{c} \mathbf{H C O}_{3}{ }^{-}, \mathrm{mmol} / \mathrm{L}\right)$ was calculated using the Henderson-Hasselbalch equation, measured values for $\mathrm{pH}$ and $\mathrm{pCO}_{2}$, and documented values for the negative logarithm of the apparent dissociation constant $\left(\mathrm{pK}_{1}{ }^{\prime}=6.095\right)$ for plasma $\mathrm{H}_{2} \mathrm{CO}_{3}$ and solubility of $\mathrm{CO}_{2}(S=0.0307 \mathrm{mmol} / \mathrm{L}$ per $\mathrm{mm} \mathrm{Hg})$ in plasma at $37^{\circ} \mathrm{C}$ (CLSI, 2009), whereby $c \mathrm{HCO}_{3}{ }^{-}=S$ $\times \mathrm{pCO}_{2} \times 10^{\left(\mathrm{pH}-\mathrm{pK} 1^{\prime}\right)}$. Base excess of extracellular fluid $\left[\mathrm{BE}_{(\mathrm{ecf})}, \mathrm{mmol} / \mathrm{L}\right]$ was calculated from the measured $\mathrm{pH}$ and $\mathrm{pCO}_{2}$, and documented values for $\mathrm{pK}_{1}{ }^{\prime}$ and $S$, such that $\mathrm{BE}_{\text {(ecf) }}=c \mathrm{HCO}_{3}{ }^{-}-24.8+16.2 \times(\mathrm{pH}-7.40)$ (CLSI, 2009). Alkalemia was defined as blood $\mathrm{pH}>7.45$ (Constable et al., 1991).

\section{Muscle Biopsy}

Muscle biopsies of the external abdominal oblique muscle were obtained on d 1, 4, 5, and 7 from each cow using a Bergstrom $6 \mathrm{~mm}$ diameter muscle biopsy cannula (ZEPF Surgical Instruments Inc., Bayport, NY). A $10-\mathrm{cm}^{2}$ section of the right paralumbar fossa was clipped and aseptically prepared. An inverted L block with $2 \%$ lidocaine was performed using an 18-gauge, 3.8-cm needle attached to the syringe. The skin and subcutaneous fat was incised with a scalpel blade. A biopsy of the external abdominal oblique muscle of approximately $100 \mathrm{mg}$ was obtained using the Bergstrom muscle biopsy cannula and the skin incision closed using tissue adhesive. All visible connective tissue and fat were quickly teased away from the biopsy sample using a 20-gauge needle and the resultant biopsy sample was placed into a preweighed 2-mL polypropylene vial (Fisherbrand cryogenic storage vial, ThermoFisher Scientific Inc., East Providence, RI) within 1 min of sampling. The vial was stored at $4^{\circ} \mathrm{C}$ for $<8 \mathrm{~h}$ before being weighed to determine sample wet weight, frozen, and stored at $-75^{\circ} \mathrm{C}$. The biopsy site was examined for signs of inflammation (swelling) and infection (heat, pain, purulent discharge) daily while the cow was on the study and then for 5 to $10 \mathrm{~d}$ after completion of the study.

The total amount of potassium, sodium, magnesium, calcium, phosphorus, and chloride in skeletal muscle tissue was determined via inductively coupled plasma mass spectrometry after drying tissue samples at $95^{\circ} \mathrm{C}$ to constant weight (Braselton et al., 1997). Electrolyte contents measured in dry skeletal muscle tissue were expressed as micrograms per gram or milligrams per gram of dry weight. The electrolyte contents in dry tissue were converted to contents in wet weight based on the measured wet weight at the time of sampling.

\section{Milk Sampling and Analysis}

Representative composite milk samples (15 mL) were obtained on the morning of d $1,4,5,6$, and 7 by the milking crew at the dairy. The milk samples were stored at $4^{\circ} \mathrm{C}$ for up to $8 \mathrm{~h}$ and then stored at $-75^{\circ} \mathrm{C}$. Samples were thawed at room temperature immediately before being analyzed for concentrations of potassium (ion-selective potentiometry) by an automated analyzer (Hitachi 911, Roche Diagnostics). Potentiometry is a useful method to measure changes in milk $[\mathrm{K}]$ over time 
because potassium in milk is $>95 \%$ dissociated, with only $4.5 \%$ being complexed (Holt et al., 1981).

\section{Urine Sampling and Analysis}

Urine $\mathrm{pH}$ was measured immediately using a test strip that measures urine $\mathrm{pH}$ in 0.5 -unit increments (Siemens Diagnostics 2181 Labstix Reagent Strips; Siemens Medical Solutions USA Inc., Malvern, PA). Samples of voided urine were collected in $15-\mathrm{mL}$ vials and aliquots transferred to $3-\mathrm{mL}$ polypropylene tubes if urine collection was successful. Urine samples were stored at $-20^{\circ} \mathrm{C}$ until further analyzed for potassium and magnesium concentration using inductively coupled plasma-optical emission spectroscopy (Optima 4300DV, Perkin Elmer Instruments LLC, Norwalk CT) and creatinine concentration (Jaffe picrate method; Hitachi 911, Roche Diagnostics). This permitted calculation of potassium and magnesium excretion and endogenous creatinine clearance. Urine electrolyte concentrations $(\mathrm{g} / \mathrm{L})$ were indexed to urine creatinine concentration $(\mathrm{mg} / \mathrm{dL})$, thereby providing a unitless value that corrects urine electrolyte concentrations for changes in urine free water.

\section{Statistical Analysis}

Results were expressed as mean \pm standard deviation, or geometric mean or median and range for parameters not normally distributed. Values were log-transformed or ranked when necessary to obtain an approximately normal distribution (as assessed by kurtosis and skewness) and achieve homogeneity of variances before statistical analysis was performed. A statistical software package (9.2, SAS Institute Inc., Cary, NC) was used for statistical analysis, and a $P$-value $<0.05$ was considered significant. To determine the effect of treatment on feed intake and milk production, the mean daily intake of the TMR and mean daily milk production on $\mathrm{d} 5,6$, and 7 were expressed as a percentage of the value on d 1 for each cow, and group median values compared using the Kruskall-Wallis test.

Repeated-measures ANOVA was used to detect differences in measured parameters between treatment groups and over time using a mixed models procedure (PROC MIXED, SAS 9.2, SAS Institute Inc.). Bonferroni-adjusted $P$-values were used when indicated by significant $\mathrm{F}$ test; between-group comparisons at the same time were to group $\mathrm{C}$, within-group comparisons were to the first value for the group on d 4 (i.e., immediately before the first treatment was administered). Primary variables of interest were plasma $[\mathrm{K}]$, milk $[K]$, urine $[K]$, skeletal muscle $K$ content (wet muscle weight basis), and any significant interaction terms on repeated-measures ANOVA. Presentation of the results of statistical analysis focused on those variables with a significant $\mathrm{F}$ test for the interaction between treatment and time or a significant $\mathrm{F}$ test for treatment.

\section{RESULTS}

\section{Animals, Sample Collection, Feed Intake, and Milk Production}

Sixteen cows (6 cows in K3 and 5 cows each in C and K12) completed the study. One cow in group K3 that completed the study developed an LDA on $\mathrm{d} 3$ that recurred after rolling on $\mathrm{d} 5$. The cow had marked ketonuria from d 4 onward and the LDA was surgically corrected immediately after completion of the study. Data from this cow were not included in the statistical analysis. One cow developed marked lameness and decreased appetite on d 3 of the study due to digital dermatitis. One cow developed marked ketonuria on $\mathrm{d}$ 3 of the study before the reduction in feed intake. Data from these 2 cows were not included in the statistical analysis. Accordingly, statistical analysis was confined to the 15 cows that remained healthy and that completed the study (5 cows in each group). Cows were $10.3 \pm 2.2 \mathrm{~d}$ in milk when they started the study (d 1).

Blood samples and muscle biopsy samples were obtained at all sampling times. Spontaneously voided urine samples were obtained within $1 \mathrm{~h}$ of blood sampling from all cows at all sampling times, except 1 cow in group K3 on d 1. A Foley catheter was successfully placed on d 4 and retained for $24 \mathrm{~h}$ in 14 cows; in 1 cow (group C), the Foley catheter could not be easily placed into the bladder because of a narrowed urethral orifice. Urine samples were retained for biochemical analysis at the assigned sampling time from this cow if urine was voided after perineal stimulation; however, urine volume was not recorded.

\section{Experimental Induction of Hypokalemia and Treatment Dose on $d 4$}

The experimental model produced clinical and clinico-pathological changes frequently observed in sick lactating dairy cows; namely, decreased milk production (Figure 1), decreased plasma $[\mathrm{K}]$ and $[\mathrm{Cl}]$, metabolic alkalosis and alkalemia (Figures 2, 3, and 4), mild dehydration as determined by change in plasma volume (Figure 4), decreased plasma glucose concentration, and increased plasma [NEFA] and [BHBA] (Table 1). Whole-body potassium depletion was suspected to be present on the morning of $\mathrm{d} 4$, as indicated by decreased $[\mathrm{K}]$ in plasma and milk in all 3 groups (Figure 2), and decreased skeletal muscle $\mathrm{K}$ content in 1 group (Figure 
$2)$. Rectal temperature, heart rate, and respiratory rate were not altered within each group on d 4 , whereas rumen contraction rate and $\mathrm{BW}$ were markedly decreased (Table 1).

Atrial fibrillation was detected in 2 cows on the morning of $\mathrm{d} 4$; both animals had marked hypokalemia $([\mathrm{K}]$; both $2.4 \mathrm{mEq} / \mathrm{L})$ and alkalemia $(\mathrm{pH} 7.54$ and 7.50$)$ but normocalcemia ([Ca], 9.3 and $9.5 \mathrm{mg} / \mathrm{dL}$ ). Both cows were randomized to receive $\mathrm{KCl}$; one cow was in group K3 and the other was in group K12. The 2 cows converted to normal sinus rhythm within $24 \mathrm{~h}$ (by the morning of $\mathrm{d} 5$ ) at which time their $[\mathrm{K}]$ had increased
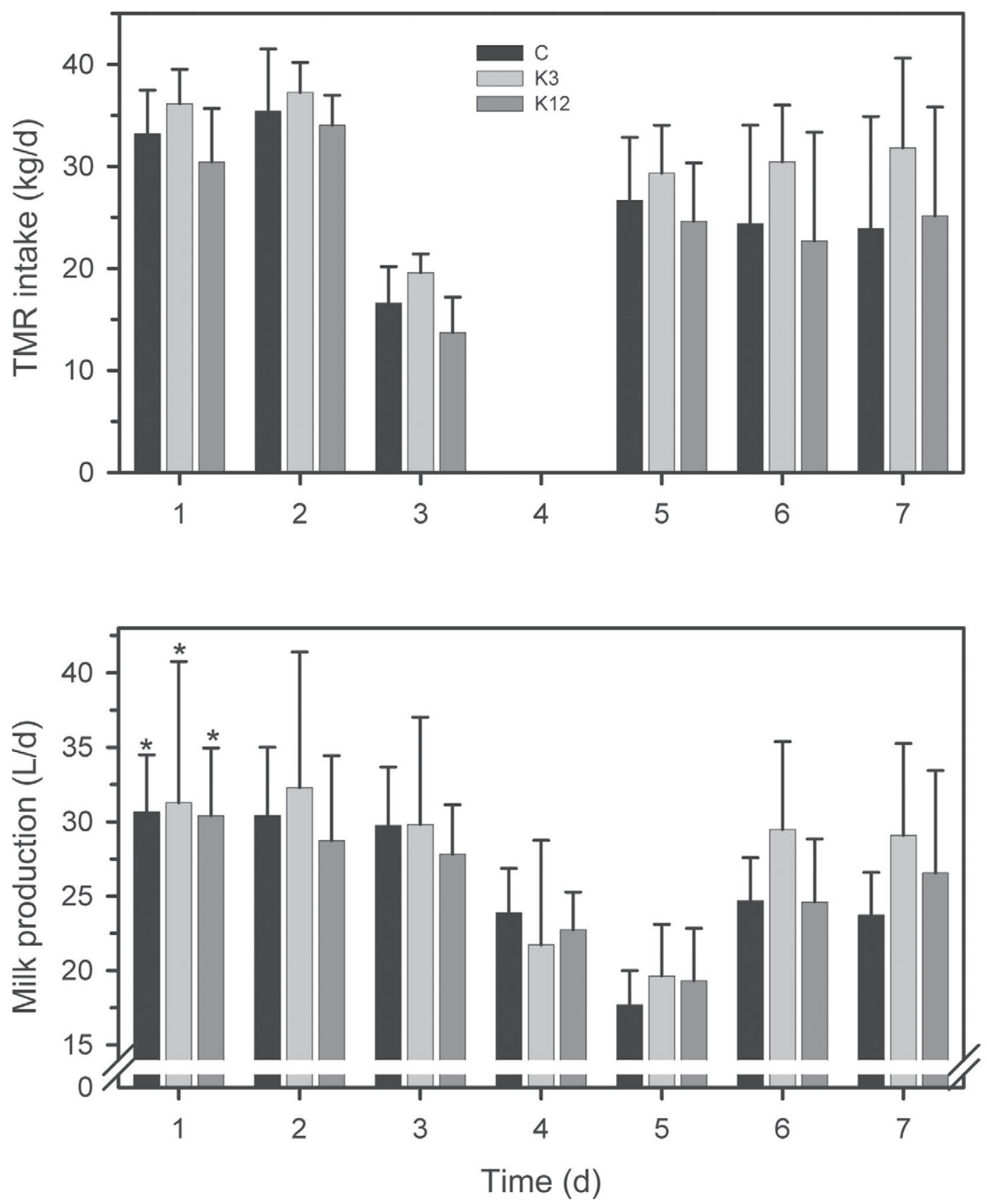

Figure 1. Mean \pm SD daily TMR intake (wet weight basis, top panel) and daily milk production (bottom panel) at different time points for cows in group $\mathrm{C}$ (black bar, $\mathrm{n}=5$ ), group K3 (light gray bar, $\mathrm{n}=5$ ), or group K12 (dark gray bar, $\mathrm{n}=5$ ) over time. Plasma K concentration was experimentally decreased in 15 multiparous Holstein-Friesian cows in early lactation by IM injection of isoflupredone acetate and furosemide, and by decreasing feed intake by $50 \%$ on d 3 and fasting on d 4 . Cows were administered $\mathrm{KCl}$ orally 8 times on d 4 at $0.05 \mathrm{~g} / \mathrm{kg}$ of BW every 3 $\mathrm{h}$ (group K3) or 2 times on d 4 at $0.20 \mathrm{~g} / \mathrm{kg}$ of BW every $12 \mathrm{~h}$ (group K12), or received no treatment (group C). *Values differ significantly ( $P$ $<0.05$, Bonferroni adjusted) from the value for the group on $\mathrm{d} 4$. 
a)

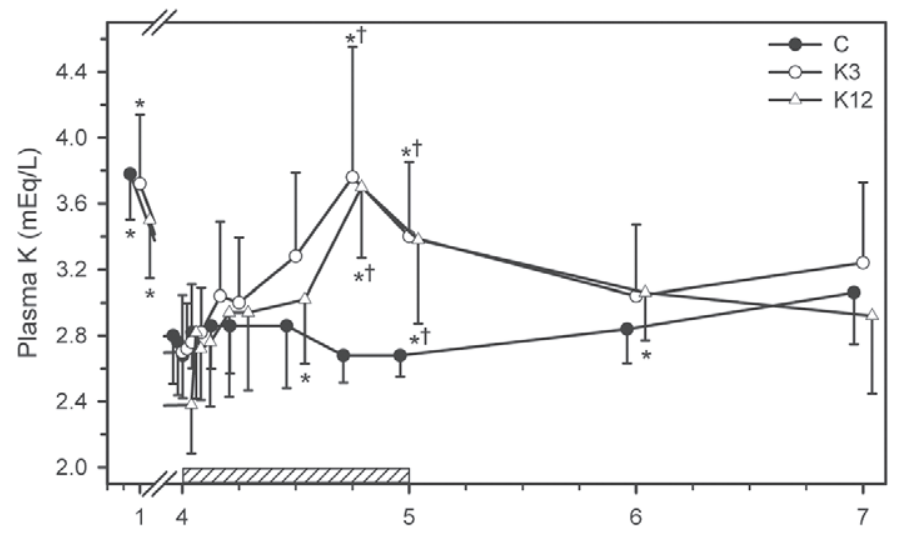

b)

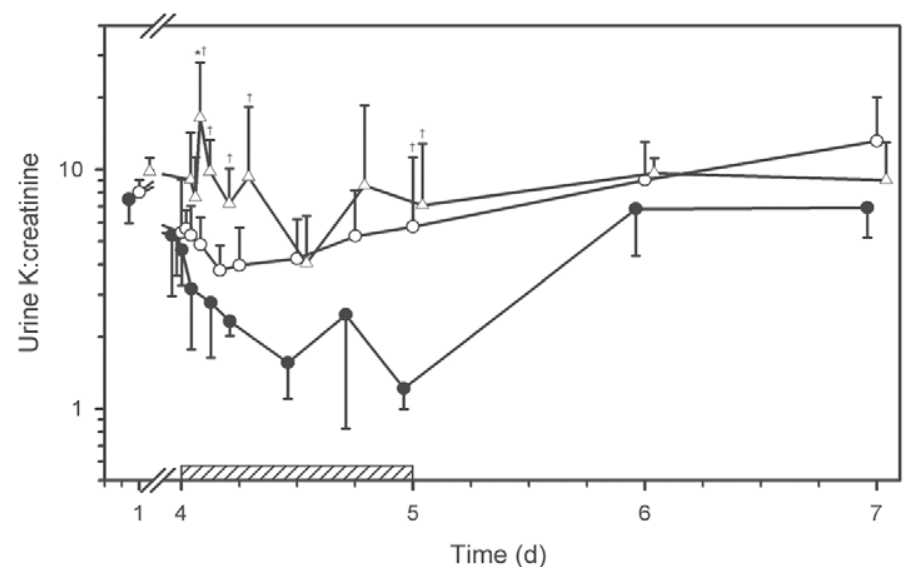

c)

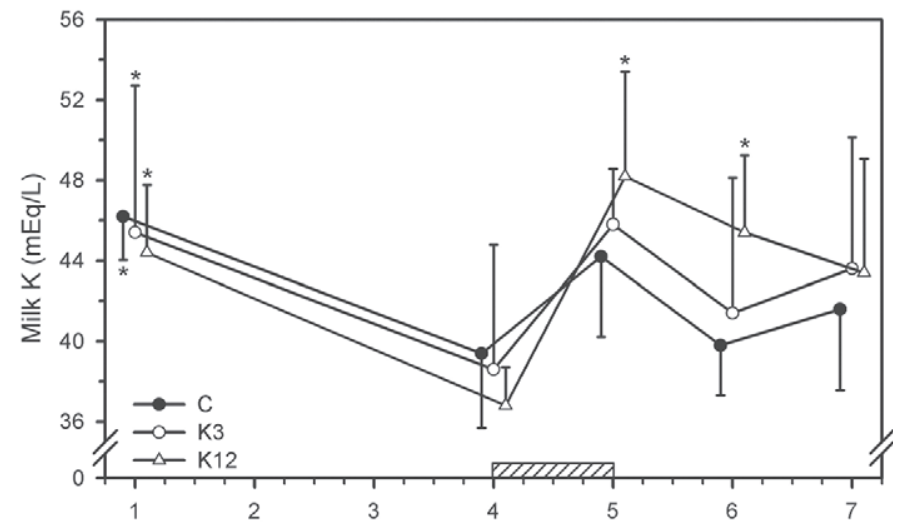

d)

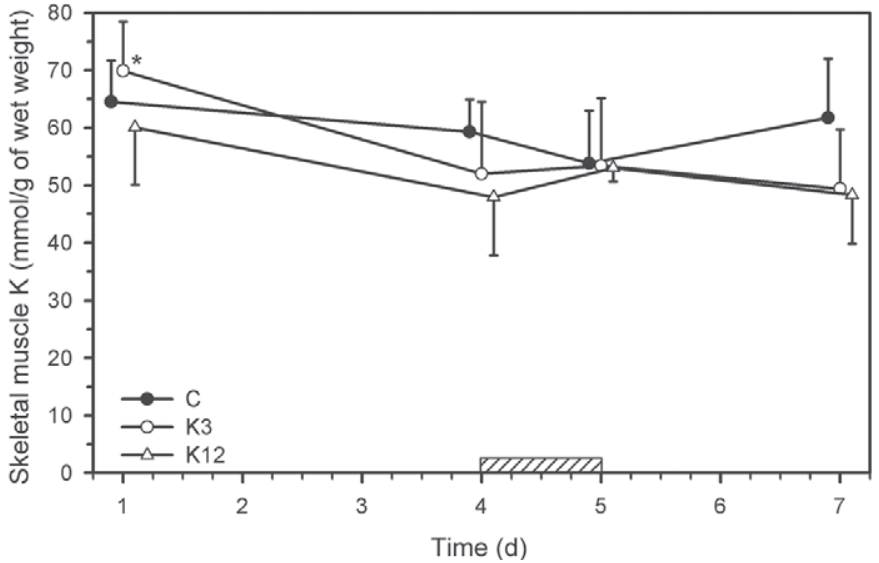

Figure 2. Mean \pm SD plasma K concentration (first panel), urine K concentration to urine creatinine concentration (second panel, semilog plot), milk K concentration (third panel), and skeletal muscle K content (fourth panel) at different time points for cows in group C $(\bullet, \mathrm{n}=5$ ), group K3 $(\bigcirc, \mathrm{n}=5)$, or group K12 $(\Delta, \mathrm{n}=5)$ over time. Plasma K concentration was experimentally decreased in 15 multiparous HolsteinFriesian cows in early lactation by IM injection of isoflupredone acetate and furosemide, and by decreasing feed intake by $50 \%$ on d 3 and fasting on d 4 . Cows were administered $\mathrm{KCl}$ orally 8 times on d 4 at $0.05 \mathrm{~g} / \mathrm{kg}$ of BW every $3 \mathrm{~h}$ (group K3) or 2 times on d 4 at $0.20 \mathrm{~g} / \mathrm{kg}$ of BW every $12 \mathrm{~h}$ (group K12), or received no treatment (group C). The hatched bar indicates the time interval that treatment was administered. Data for group C and group K12 are slightly offset to improve readability. †Values differ significantly $(P<0.05$, Bonferroni adjusted) from group C at the same time; *values differ significantly $(P<0.05$, Bonferroni adjusted) from the first value for the group on $\mathrm{d} 4$ (immediately before the first treatment was administered).

to 3.0 and $3.0 \mathrm{mEq} / \mathrm{L}$, respectively, and their blood $\mathrm{pH}$ decreased to 7.47 and 7.47 , respectively.

Cows were administered the following amounts of $\mathrm{KCl}$ on d 4; group C, 0 g; group K3, $230 \pm 17$ g; group $\mathrm{K} 12,219 \pm 35 \mathrm{~g}$. We observed no statistical difference in the $24-\mathrm{h} \mathrm{KCl}$ dose administered between groups $\mathrm{K} 3$ and $\mathrm{K} 12$. The administered oral $\mathrm{KCl}$ dose was equivalent to the following oral $\mathrm{K}$ doses; group $\mathrm{C}, 0$ g; group $\mathrm{K} 3,121 \pm 9 \mathrm{~g}$; group K12, $115 \pm 18 \mathrm{~g}$, with no statistical difference in the dose between groups K3 and K12.

Significant treatment $\times$ time effects were detected and mean values differed from those immediately before treatment on d 4 for plasma $[\mathrm{K}](P<0.0001)$ and urinary $[\mathrm{K}]$ to creatinine ratio $(P=0.0021)$, plasma $[\mathrm{Cl}](P=0.017)$ and $c \mathrm{HCO}_{3}{ }^{-}(P=0.041)$, and blood
$\mathrm{pH}(P=0.048)$. Significant treatment effects were detected for $\mathrm{pCO}_{2}(P=0.019), c \mathrm{HCO}_{3}{ }^{-}(P=0.047)$ and $[\mathrm{P}](P=0.034)$.

\section{Plasma Biochemical Concentrations}

Plasma $[\mathrm{K}]$ and $[\mathrm{Cl}]$ were decreased in cows administered isoflupredone acetate and furosemide and fasted (Figures 2 and 3). As anticipated, oral administration of $\mathrm{KCl}$ rapidly increased plasma $\mathrm{K}$ and $\mathrm{Cl}$ concentrations, with the maximal increase in plasma $[\mathrm{K}]$ and $[\mathrm{Cl}]$ occurring approximately $18 \mathrm{~h}$ after the start of administration in groups K3 and K12. Plasma and milk [K] and skeletal muscle $\mathrm{K}$ content on $\mathrm{d} 7$ were not increased above pretreatment values (d 4) in any group. 
a)

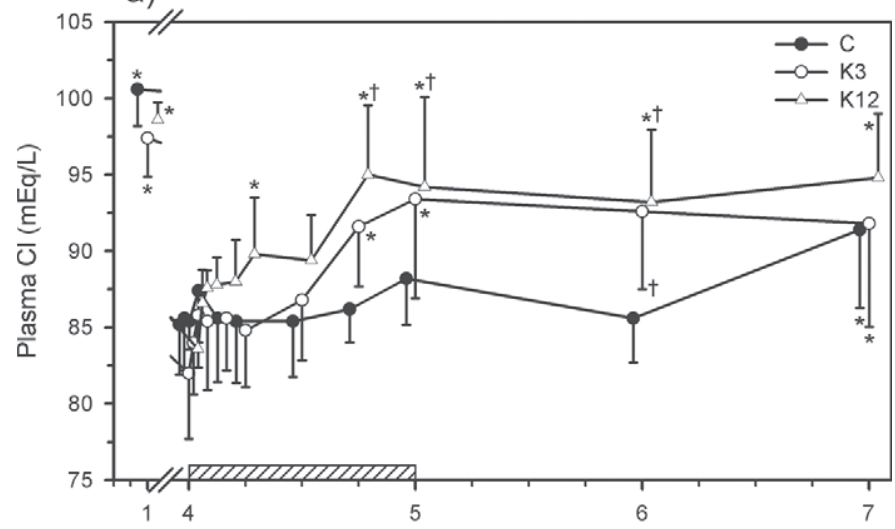

b)

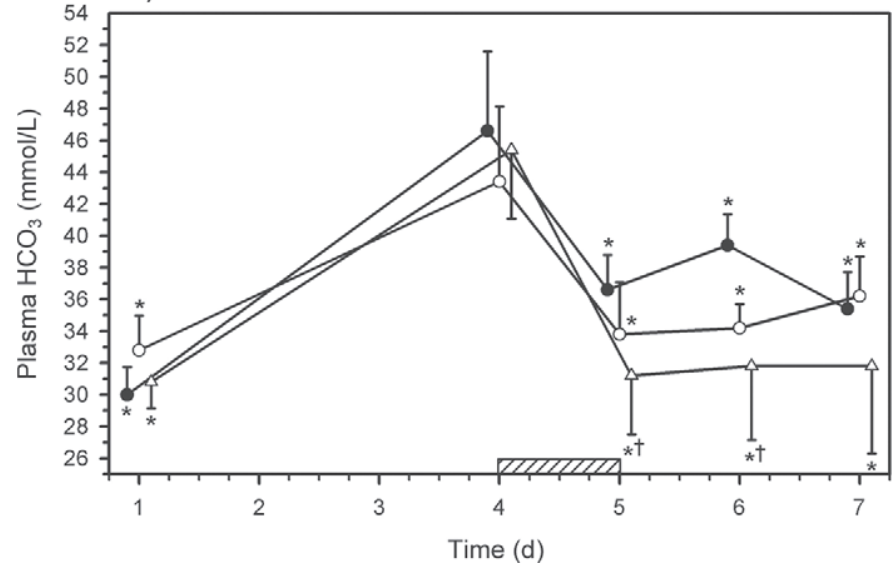

Figure 3. Mean $\pm \mathrm{SD}$ plasma $\mathrm{Cl}$ concentration (top panel) and plasma bicarbonate concentration (bottom panel) at different time points for cows in group $\mathrm{C}(\bullet, \mathrm{n}=5)$, group $\mathrm{K} 3(\mathrm{O}, \mathrm{n}=5)$, or group $\mathrm{K} 12(\Delta, \mathrm{n}=5)$ over time. Plasma $\mathrm{K}$ concentration was experimentally decreased in 15 multiparous Holstein-Friesian cows in early lactation by IM injection of isoflupredone acetate and furosemide, and by decreasing feed intake by $50 \%$ on d 3 and fasting on d 4 . Cows were administered $\mathrm{KCl}$ orally 8 times on d 4 at $0.05 \mathrm{~g} / \mathrm{kg}$ of BW every $3 \mathrm{~h}$ (group K3) or 2 times on $\mathrm{d} 4$ at $0.20 \mathrm{~g} / \mathrm{kg}$ of BW every $12 \mathrm{~h}$ (group $\mathrm{K} 12$ ), or received no treatment (group C). The hatched bar indicates the time interval that treatment was administered. Data for group $\mathrm{C}$ and group K12 are slightly offset to improve readability. †Values differ significantly $(P<0.05$, Bonferroni adjusted) from group $\mathrm{C}$ at the same time; *values differ significantly $(P<0.05$, Bonferroni adjusted $)$ from the first value for the group on $\mathrm{d} 4$ (immediately before the first treatment was administered).

Plasma $[\mathrm{Mg}]$ did not change in cows up to d 4 (Figure 5); however, oral administration of $\mathrm{KCl}$ decreased plasma $[\mathrm{Mg}]$, with a significant decrease being evident in group K12 at $18 \mathrm{~h}$ and $24 \mathrm{~h}$ (d 5) after the start of treatment, and in group K3 at $2 \mathrm{~d}$ after the start of treatment (d 6).

Small changes in plasma $[\mathrm{Na}],[\mathrm{Ca}],[\mathrm{P}]$, and [total protein] were detected over time with no clear pattern, whereas plasma [creatinine] remained constant. a)

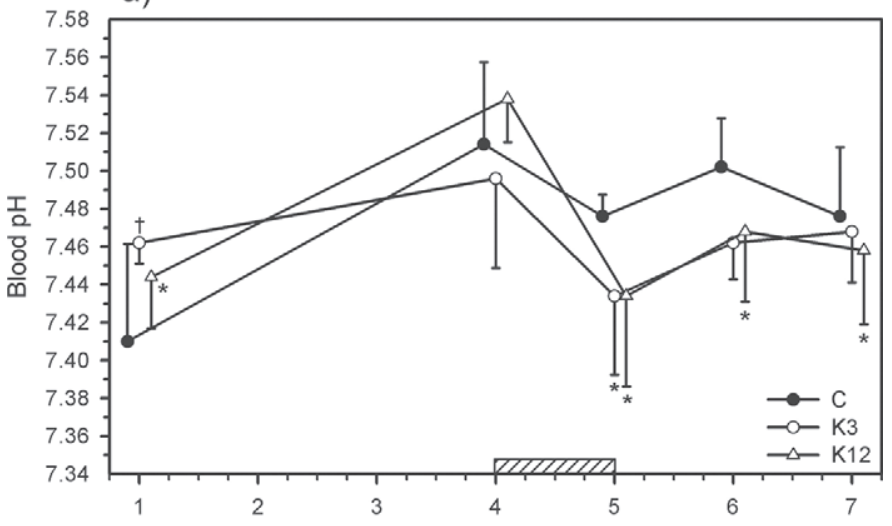

b)

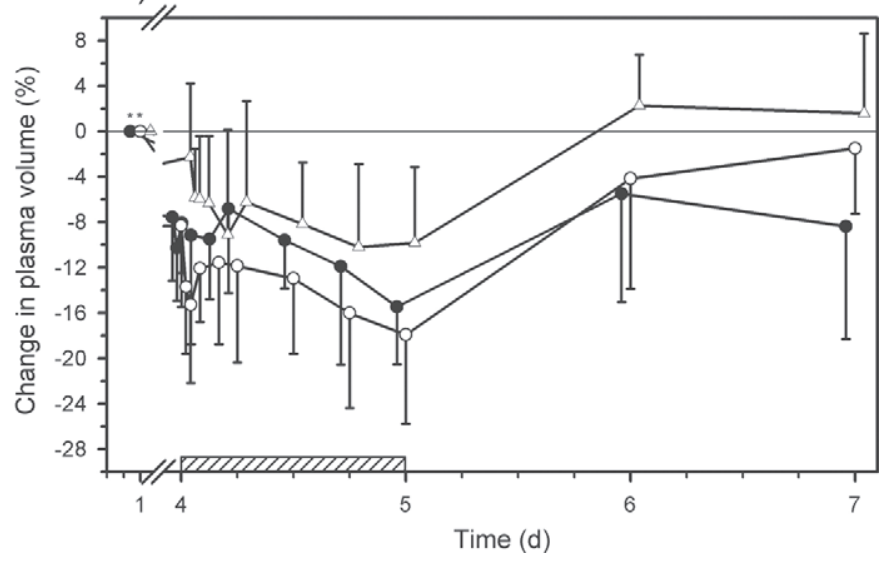

Figure 4. Mean $\pm \mathrm{SD}$ blood $\mathrm{pH}$ (top panel) and percentage change in plasma volume (bottom panel) at different time points for cows in group $\mathrm{C}(\bullet, \mathrm{n}=5)$, group $\mathrm{K} 3(\mathrm{O}, \mathrm{n}=5)$, or group $\mathrm{K} 12(\Delta, \mathrm{n}=5)$ over time. Plasma $\mathrm{K}$ concentration was experimentally decreased in 15 multiparous Holstein-Friesian cows in early lactation by IM injection of isoflupredone acetate and furosemide, and by decreasing feed intake by $50 \%$ on $\mathrm{d} 3$ and fasting on $\mathrm{d} 4$. Cows were administered $\mathrm{KCl}$ orally 8 times on d 4 at $0.05 \mathrm{~g} / \mathrm{kg}$ of BW every $3 \mathrm{~h}$ (group K3) or 2 times on d 4 at $0.20 \mathrm{~g} / \mathrm{kg}$ of BW every $12 \mathrm{~h}$ (group K12), or received no treatment (group C). The hatched bar indicates the time interval that treatment was administered. Data for group C and group K12 are slightly offset to improve readability. †Values differ significantly $(P<0.05$, Bonferroni adjusted) from group $\mathrm{C}$ at the same time; *values differ significantly $(P<0.05$, Bonferroni adjusted $)$ from the first value for the group on d 4 (immediately before the first treatment was administered).

\section{Feed Intake, Milk Production, and Energy Metabolism}

Mean daily intake of the TMR on d 5, 6, and 7 (Figure 1), when expressed as a percentage of the intake on $\mathrm{d} 1$, did not differ between groups $[P=0.70$; group C, $71 \%$ (42, 105\%); group K3, 91\% (64, 98\%); group $\mathrm{K} 12,92 \%$ (29, 113\%); median values and range in parentheses]. Mean daily milk production on d 5, 6, and 7 (Figure 1), when expressed as a percentage of the milk production on $\mathrm{d} 1$, did not differ between groups $[P$ 
Table 1. Mean \pm SD values (or geometric mean and range in parentheses) for physical examination findings and plasma biochemical concentrations at different time points for 15 Holstein-Friesian cows in early lactation with plasma $\mathrm{K}$ concentration that was experimentally decreased by IM injection of isoflupredone acetate and furosemide, and by decreasing feed intake by $50 \%$ on $\mathrm{d} 3$ and fasting on $\mathrm{d} 4$

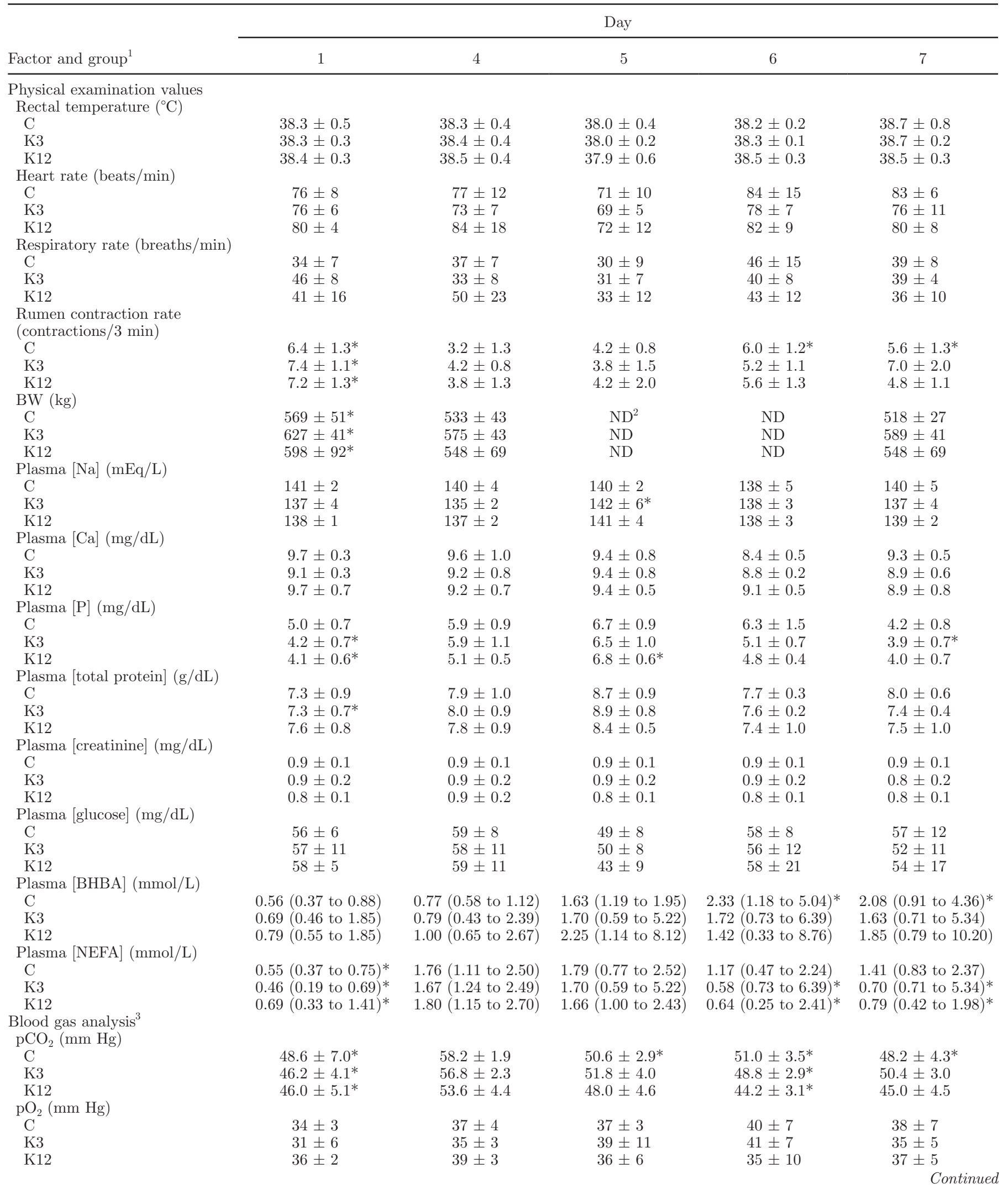


Table 1 (Continued). Mean \pm SD values (or geometric mean and range in parentheses) for physical examination findings and plasma biochemical concentrations at different time points for 15 Holstein-Friesian cows in early lactation with plasma $\mathrm{K}$ concentration that was experimentally decreased by IM injection of isoflupredone acetate and furosemide, and by decreasing feed intake by $50 \%$ on d 3 and fasting on d 4

\begin{tabular}{|c|c|c|c|c|c|}
\hline Factor and group ${ }^{1}$ & \multicolumn{5}{|c|}{ Day } \\
\hline \multicolumn{6}{|c|}{ Urine biochemical analysis } \\
\hline \multicolumn{6}{|c|}{ Urine $\mathrm{pH}$} \\
\hline $\mathrm{C}$ & $8.5 \pm 0.0$ & $8.4 \pm 0.2$ & $7.1 \pm 0.8$ & $8.5 \pm 0.0$ & $8.3 \pm 0.4$ \\
\hline K3 & $8.4 \pm 0.2$ & $8.4 \pm 0.2$ & $8.0 \pm 1.1$ & $8.5 \pm 0.0$ & $8.5 \pm 0.0$ \\
\hline K12 & $8.5 \pm 0.0$ & $8.1 \pm 0.9$ & $7.2 \pm 1.1$ & $7.9 \pm 1.3$ & $8.0 \pm 1.1$ \\
\hline K3 & $100 \pm 27$ & $78 \pm 26$ & $108 \pm 48$ & $118 \pm 51$ & $76 \pm 34$ \\
\hline K12 & $97 \pm 16$ & $85 \pm 56$ & $90 \pm 50$ & $94 \pm 28$ & $86 \pm 39$ \\
\hline
\end{tabular}

${ }^{1}$ Cows were administered $\mathrm{KCl}$ orally 8 times on $\mathrm{d} 4$ at $0.05 \mathrm{~g} / \mathrm{kg}$ of BW every $3 \mathrm{~h}$ (group K3) or 2 times on d 4 at $0.20 \mathrm{~g} / \mathrm{kg}$ of BW every $12 \mathrm{~h}$ (group K12), or received no treatment (group C).

${ }^{2} \mathrm{ND}=$ not determined.

${ }^{3} \mathrm{pCO}_{2}$ and $\mathrm{pO}_{2}=$ partial pressure of $\mathrm{CO}_{2}$ and $\mathrm{O}_{2}$, respectively.

${ }^{*} P<0.05$ (Bonferroni adjusted): differ significantly from the first value for the group on $\mathrm{d} 4$ (immediately before the first treatment was administered). There were no significant differences in studied variables between the control group and groups K12 and K3 on any day.

$=0.20 ;$ group C, $70 \%(65,88 \%)$; group K3, $79 \%(74$, $122 \%)$; group $\mathrm{K} 12,84 \%$ (66, 95\%); median values and range in parentheses].

A significant treatment or interaction effect for plasma [glucose], [NEFA], and [BHBA] was not present; however, plasma [NEFA] decreased in groups $\mathrm{K} 3$ and K12 after d 4 but not in group C, and plasma [BHBA] increased in group $\mathrm{C}$ after $\mathrm{d} 4$ but not in groups $\mathrm{K} 3$ and K12 (Table 1).

\section{Acid-Base Balance}

As expected in lactating dairy cows administered isoflupredone acetate and furosemide and feed restricted, all acid-base indices changed over time (Figure 3, Figure 4, Table 1). Alkalemia due to metabolic alkalosis (as demonstrated by the marked increased in the plasma bicarbonate concentration) on d 4 was partially compensated by an increased venous $\mathrm{pCO}_{2}$ with no detectable change in respiratory rate. Oral administration of $\mathrm{KCl}$ in groups $\mathrm{K} 3$ and $\mathrm{K} 12$ decreased plasma bicarbonate concentration within $24 \mathrm{~h}$, with group K12 having a lower plasma bicarbonate concentration than the control group on d 5 and 6 (Figure 3).

\section{Muscle Biopsy}

Skeletal muscle K content (wet weight basis) varied markedly from cow to cow; such variability may have been due, in part, to the relatively small sample size of tissue analyzed (mean, $92 \mathrm{mg}$; Figure 2). Skeletal muscle $\mathrm{K}$ content was decreased on $\mathrm{d} 4$ in group K12, indicating whole-body $\mathrm{K}$ depletion, and was not significantly decreased in group K3 or group C. Changes in skeletal muscle content for the $3 \mathrm{~d}$ after $\mathrm{d} 4 \mathrm{did}$ not reveal a consistent pattern.

\section{Milk Biochemical Analysis}

Milk K concentration was decreased on d 4 in all 3 groups due to the administration of isoflupredone acetate, furosemide, and fasting (Figure 2). The amount of $\mathrm{K}$ lost in the milk over $24 \mathrm{~h}$ starting on $\mathrm{d} 4$ was similar in all 3 groups: group C, $42 \pm 10$ g; group K3, $44 \pm 12$ g; group K12, $42 \pm 10$ g. In other words, cows administered $\mathrm{KCl}$ every $12 \mathrm{~h}$ did not have an increased loss of $\mathrm{K}$ into their milk relative to cows administered $\mathrm{KCl}$ every $3 \mathrm{~h}$.

\section{Urine Biochemical Analysis}

Endogenous creatinine clearance was constant over $24 \mathrm{~h}$ on $\mathrm{d} 4$ for all 3 groups (overall mean, $1.75 \mathrm{~mL} /$ min per $\mathrm{kg}$ ). The 24 -h urine volume on $\mathrm{d} 4$ was higher in group $\mathrm{K} 3(12.7 \pm 2.5 \mathrm{~L}, P=0.015)$ than in group $\mathrm{C}(8.0 \pm 2.0 \mathrm{~L})$; the 24 -h urine volume in group K12 $11.9 \pm 2.6 \mathrm{~L})$ tended $(P=0.035$, Bonferroni-adjusted $P$-value for significance $<0.025)$ to be higher than that in group C. Because mean daily urine volume differed between groups (when measured on d 4), but urinary [creatinine] remained constant on $\mathrm{d} 1,4,5,6$, and 7 (Table 1), urine electrolyte concentrations (expressed in $\mathrm{g} / \mathrm{L}$ ) were indexed to urine creatinine concentration (in $\mathrm{mg} / \mathrm{dL}$ ). This provided a unitless value for the ratio of urine electrolyte concentration to the urine creatinine concentration.

Cows in group K12, but not group K3, had a higher urinary $[\mathrm{K}]$ : [creatinine] than cows in group $\mathrm{C}$ for much 

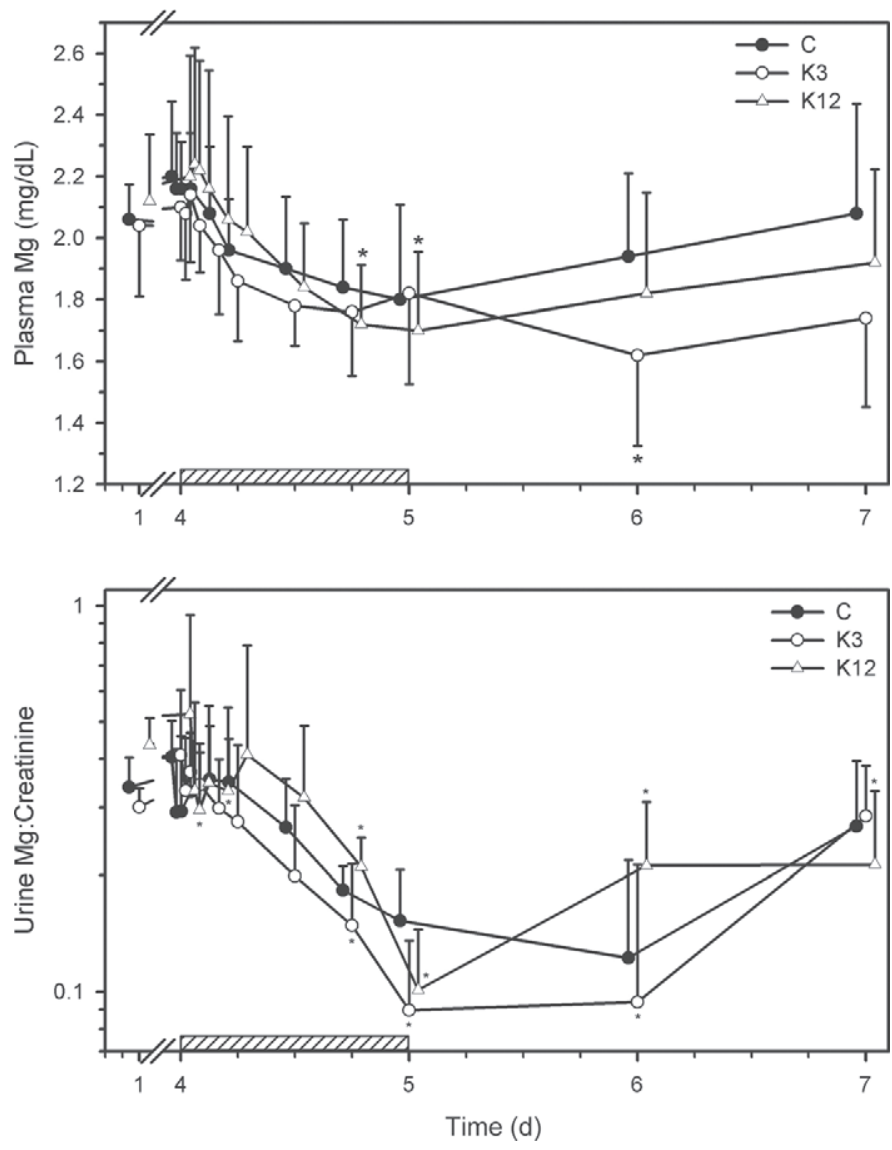

Figure 5. Mean \pm SD plasma magnesium concentration (top panel) and urine magnesium concentration (bottom panel) at different time points for cows in group $\mathrm{C}(\bullet, \mathrm{n}=5)$, group $\mathrm{K} 3(\mathrm{O}, \mathrm{n}=5)$, or group K12 $(\Delta, \mathrm{n}=5)$ over time. Plasma $\mathrm{K}$ concentration was experimentally decreased in 15 multiparous Holstein-Friesian cows in early lactation by IM injection of isoflupredone acetate and furosemide, and by decreasing feed intake by $50 \%$ on $\mathrm{d} 3$ and fasting on $\mathrm{d} 4$. Cows were administered $\mathrm{KCl}$ orally 8 times on $\mathrm{d} 4$ at $0.05 \mathrm{~g} / \mathrm{kg}$ of BW every $3 \mathrm{~h}$ (group K3) or 2 times on $\mathrm{d} 4$ at $0.20 \mathrm{~g} / \mathrm{kg}$ of BW every $12 \mathrm{~h}$ (group K12), or received no treatment (group C). The hatched bar indicates the time interval that treatment was administered. Data for group C and group K12 are slightly offset to improve readability. ${ }^{*}$ Values differ significantly $(P<0.05$, Bonferroni adjusted) from the first value for the group on d 4 (immediately before the first treatment was administered).

of the 24-h period immediately after treatment (Figure 2 ). More importantly, the amount of $\mathrm{K}$ excreted in the urine on $\mathrm{d} 4(24 \mathrm{~h})$ in group K12 $(52 \pm 9 \mathrm{~g})$ and group K3 $(49 \pm 14 \mathrm{~g})$ was greater than the amount excreted in group C ( $23 \pm 7 \mathrm{~g} ; P=0.0019$; vs. group K12, $P=$ 0.0037 ; vs. group K3). We observed no difference in the 24-h mean urinary excretion of $\mathrm{K}$ between groups K12 and $\mathrm{K} 3(P=0.70)$. In other words, cows administered $\mathrm{KCl}$ every $12 \mathrm{~h}$ did not have an increased loss of $\mathrm{K}$ in their urine relative to cows administered $\mathrm{KCl}$ every $3 \mathrm{~h}$.

Urinary $[\mathrm{Mg}]:[$ creatinine] was numerically decreased during fasting for cows in all 3 groups, with some recovery after the end of fasting (Figure 5). The decrease in urinary $[\mathrm{Mg}]:[$ creatinine] was statistically significant at many time points for group K12 and for several time points for group K3. More importantly, the amount of $\mathrm{Mg}$ (overall mean, $2.2 \mathrm{~g}$ ) lost in the urine over $24 \mathrm{~h}$ on d 4 was similar for all 3 groups.

\section{DISCUSSION}

The major finding of the study reported here was that a 24-h dose rate of $\mathrm{KCl}$ of $0.4 \mathrm{~g} / \mathrm{kg}$ of $\mathrm{BW}$ appeared suitable for the initial treatment of lactating dairy cattle with moderate hypokalemia, with no clear difference between 2 large doses (group K12) or multiple small doses (group K3). Our finding that plasma and milk $\mathrm{K}$ concentrations and skeletal muscle $\mathrm{K}$ content on $\mathrm{d} 7$ were not increased above pretreatment values (d 4) in the 2 treatment groups suggests that the duration of treatment was too short or that feed intake was not adequate for the level of milk production.

Skeletal muscle K content is considered the most sensitive and specific method for assessing whole-body $\mathrm{K}$ status (Johnson et al., 1991) and therefore is considered the reference method. Skeletal muscle is considered the best tissue to sample because it contains approximately $75 \%$ of the whole-body stores of K. A standardized muscle should be evaluated in cattle because differences in $\mathrm{K}$ content of greater than $15 \%$ are present in individual animals and this muscle-to-muscle variation is greater than that produced by breed (Sim and Wellington, 1976). Skeletal muscle K content in the external abdominal oblique muscle was measured to determine the clinical utility of measuring the $\mathrm{K}$ content of this muscle during surgical correction of LDA by right flank omentopexy with the cow in a standing position. Our failure to identify marked and consistent changes in skeletal $\mathrm{K}$ content following injections of isoflupredone acetate and furosemide, as well as following treatment, may reflect the absence of whole-body $\mathrm{K}$ depletion; possibly a longer duration of decreased feed intake or higher level of milk production is required to mimic naturally occurring cases of severe hypokalemia in lactating dairy cows.

The purpose of measuring milk $[\mathrm{K}]$ was to calculate milk $\mathrm{K}$ losses and to determine whether measuring milk $[\mathrm{K}]$ would be clinically useful for monitoring the response to treatment in hypokalemic dairy cows. Milk $\mathrm{K}$ concentration is theoretically more sensitive than serum or plasma $[\mathrm{K}]$ in detecting whole-body $\mathrm{K}$ depletion in individual cows because milk $[\mathrm{K}]$ is constant for an individual cow over a short period. Moreover, milk $[\mathrm{K}]$ is closer to intracellular fluid constituents than serum or plasma $[\mathrm{K}]$ and, on this basis, may provide useful insight into $\mathrm{K}$ homeostasis over time in an individual cow. Potassium depletion in lactating dairy cows 
caused milk K concentration to decrease from 37.1 to $32.7 \mathrm{mmol} / \mathrm{L}$ (Pradhan and Hemken, 1968); this was a greater percentage decrease than that in plasma or whole blood of cattle with whole-body $\mathrm{K}$ depletion. However, milk $[\mathrm{K}]$ changes during lactation, being 42 $\mathrm{mmol} / \mathrm{L}$ in early lactation, $40 \mathrm{mmol} / \mathrm{L}$ in mid lactation, and $27 \mathrm{mmol} / \mathrm{L}$ in late lactation, with a mean bulk milk $[\mathrm{K}]$ of $37 \mathrm{mmol} / \mathrm{L}$ (Gaucheron, 2005). The large change in milk $[\mathrm{K}]$ during lactation means that there is marked individual variation in milk $[\mathrm{K}]$ in healthy cattle, with variations of up to $50 \%$ occurring between cows (Sasser et al., 1966; Pradhan and Hemken, 1968; Sattler et al., 2001). This variability appears to be due to changes in milk fat, protein, and lactose percentage, with milk $[\mathrm{K}]$ being most strongly associated $(\mathrm{r}=-0.74)$ with milk lactose concentration (Oshima and Fuse, 1977). The relationship between $\mathrm{K}$ and lactose concentration in milk is due to the fact that these are important contributors to milk osmolality, which is constant and isotonic (Oshima and Fuse, 1977). The large cow-to-cow variability in milk $[\mathrm{K}]$ makes it difficult to identify a suitable cut-point for milk $[\mathrm{K}]$ that accurately predicts whole-body $\mathrm{K}$ depletion in sick lactating dairy cows. However, monitoring milk $[\mathrm{K}]$ in individual cows may have clinical utility as a monitoring tool to gauge the response to therapy with $\mathrm{KCl}$.

The purpose of measuring the ratio of urine $[\mathrm{K}]$ to [creatinine] was to determine whether this measurement would be clinically useful in monitoring the response to treatment. Urine K concentrations are normally high in lactating dairy cattle but variable, with a mean fractional clearance of $82 \%$ and a coefficient of variation of $61 \%$ (Neiger and Hagemoser, 1985). The large variability in urine $\mathrm{K}$ concentration would make it difficult to produce a suitable cut-point for identifying wholebody $\mathrm{K}$ depletion. However, determination of urine $\mathrm{K}$ concentration has clinical utility in an individual cow ingesting a constant diet over time because it reflects $\mathrm{K}$ homeostasis.

Hypokalemia commonly occurs due to a compartmental shift of $\mathrm{K}$ from the extracellular to intracellular space in cattle with hyperinsulinemia due to hyperglycemia or alkalemia due to metabolic alkalosis (Svendsen, 1969; Grünberg et al., 2006; Constable et al., 2013). The study design did not allow us to determine the relative contribution of alkalemia and metabolic alkalosis to the experimentally induced hypokalemia. Alkalemia and metabolic alkalosis are frequently present in dairy cattle with clinical signs of severe hypokalemia (Sielman et al., 1997; Sattler et al., 1998; Peek et al., 2000). It is widely accepted that serum $[\mathrm{K}]$ accurately reflects intracellular $\mathrm{K}$ stores in euglycemic or hypoglycemic animals with blood $\mathrm{pH}$ within the reference range; however, it is generally believed that in severe alkalemia, serum $[\mathrm{K}]$ must be $<2.5 \mathrm{mEq} / \mathrm{L}$ to reflect the presence of significant intracellular $\mathrm{K}$ depletion (Burnell and Scribner, 1957). Experimental induction of metabolic alkalosis by oral administration of sodium bicarbonate in 3 Jersey cows caused marked metabolic (strong ion) alkalosis, hypokalemia, and an increase in muscle $\mathrm{K}$ concentration of 6 to $10 \%$, indicating an intracellular shift of $\mathrm{K}$ from the extracellular space to the intracellular space (Svendsen, 1969). The association between hypokalemia and alkalemia raises the interesting question as to the change in skeletal muscle $\mathrm{K}$ concentration in dairy cattle with LDA; affected animals are inappetant, which will lead to whole-body $\mathrm{K}$ depletion and decreased skeletal muscle $\mathrm{K}$ concentration. However, cattle with LDA also have alkalemia and metabolic (strong ion) alkalosis, which will lead to increased skeletal muscle $\mathrm{K}$ concentration, and sequestration of K-rich abomasal fluid associated with abomasal displacement, which will lead to decreased K absorption.

Marked abnormalities in serum [K], both hypokalemia and hyperkalemia, are frequently associated with cardiac arrhythmias (Fosha-Dolezal and Fedde, 1988). Although no large-scale studies have examined the association between hypokalemia and cardiac arrhythmias in adult cattle, we have frequently observed hypokalemia, hypocalcemia, and alkalemia in lactating dairy cattle with LDA and atrial fibrillation. In the study reported here, 2 of 15 lactating dairy cows with experimentally induced hypokalemia and alkalemia developed atrial fibrillation that resolved within $24 \mathrm{~h}$ of administration of $\mathrm{KCl}$, accompanied by an increase in plasma $[\mathrm{K}]$ and a decrease in blood $\mathrm{pH}$. Atrial fibrillation was diagnosed in 4 of 10, 2 of 14, and 5 of 17 cows with naturally acquired hypokalemia (Sielman et al., 1997; Sattler et al., 1998; Peek et al., 2000), and in 1 of 7 lactating dairy cows with experimentally induced hypokalemia following i.m. administration of two 20$\mathrm{mg}$ doses of isoflupredone acetate at a 48-h interval (Coffer et al., 2006). Taken together, these findings suggest that hypokalemia plays a role in the development of atrial fibrillation in adult cattle.

We did not observe a significant treatment or interaction effect between treatment and time for feed intake, milk production, or plasma [glucose], [NEFA], or $[\mathrm{BHBA}]$, despite moderate numerical differences in some of these variables between groups. This result is similar to the findings of many other short-term studies in early lactation dairy cows and most likely reflects a type II error (inadequate statistical power). Relatively large between-cow variability in early lactation means that group sizes greater than 5 , such as 15 cows/group (Fürll et al., 2010), are usually needed to detect an effect on energy metabolism, feed intake, or milk pro- 
duction. Nevertheless, our findings that plasma [NEFA] decreased in groups $\mathrm{K} 3$ and K12, but not in group C, after d 4, and that plasma [BHBA] increased in group $\mathrm{C}$, but not in groups $\mathrm{K} 3$ and $\mathrm{K} 12$, after d 4, suggest that oral $\mathrm{KCl}$ administration decreased peripheral fat mobilization in cattle with experimentally induced hypokalemia.

Our findings suggest that a prospective clinical study in sick dairy cows in early lactation is indicated to determine the clinical efficacy and safety of oral $\mathrm{KCl}$ (daily dose of $0.4 \mathrm{~g} / \mathrm{kg}$ of $\mathrm{BW}$ in 2 divided doses) in treating cattle with naturally acquired hypokalemia. Our results indicate that oral $\mathrm{KCl}$ may need to be administered for more than $1 \mathrm{~d}$ in hypokalemic cattle.

\section{ACKNOWLEDGMENTS}

The authors thank all the staff at the Purdue Dairy Research and Education Center, Department of Animal Sciences (Purdue University), Berdine Martin (Department of Nutrition Science at Purdue University), the staff at the Clinical Pathology Laboratory, College of Veterinary Medicine (University of Illinois at UrbanaChampaign), and the staff at the Diagnostic Center for Population and Animal Health (Michigan State University, East Lansing) for their valuable technical assistance. The study was supported, in part, by a grant from Boehringer Ingelheim LLC (Ingelheim, Germany).

\section{REFERENCES}

Braselton, W. E., K. J. Stuart, T. P. Mullaney, and T. H. Herdt. 1997. Biopsy mineral analysis by inductively coupled plasma-atomic emission spectroscopy with ultrasonic nebulization. J. Vet. Diagn. Invest. 9:395-400.

Burnell, J. M., and B. H. Scribner. 1957. Serum potassium concentration as a guide to potassium need. J. Am. Med. Assoc. 164:959962 .

CLSI (Clinical and Laboratory Standards Institute). 2009. Blood gas and $\mathrm{pH}$ analysis and related measurements. CLSI document C46A2. Approved guidelines. 2nd ed. Clinical and Laboratory Standards Institute, Wayne, PA.

Coffer, N. J., N. Frank, S. B. Elliott, C. D. Young, and S. R. van Amstel. 2006. Effects of dexamethasone and isoflupredone acetate on plasma potassium concentrations and other biochemical measurements in dairy cows in early lactation. Am. J. Vet. Res. 67:1244-1251.

Constable, P. D. 2003. Fluids and Electrolytes. Pages 1-40 in Clinical Pharmacology: Veterinary Clinics of North America, Food Animal Practice. Vol. 19. G. W. Brumbaugh, ed. W. B. Saunders Company, Philadelphia, PA.

Constable, P. D., W. Grünberg, and L. Carstensen. 2009. Comparative effects of two oral rehydration solutions on milk clotting, abomasal luminal $\mathrm{pH}$, and abomasal emptying rate in suckling calves. J. Dairy Sci. 92:296-312.

Constable, P. D., W. Grünberg, R. Staufenbiel, and H. R. Stämpfli. 2013. Clinicopathological associations with hypokalemia in lactating dairy cows with abomasal displacement or abomasal volvulus. J. Am. Vet. Med. Assoc. 242:826-835.

Constable, P. D., G. St. Jean, B. L. Hull, D. M. Rings, and G. F. Hoffsis. 1991. Preoperative prognostic indicators in cattle with abomasal volvulus. J. Am. Vet. Med. Assoc. 198:2077-2085.
Dennis, J., and F. G. Harbaugh. 1948. The experimental alteration of blood potassium and calcium levels in cattle. Am. J. Vet. Res. 9:20-25.

Fosha-Dolezal, S. R., and M. R. Fedde. 1988. Serum potassium during exercise in Hereford calves: Influence of physical conditioning. J. Appl. Physiol. 65:1360-1366.

Fürll, M., A. Deniz, B. Westphal, C. Illing, and P. D. Constable. 2010. Effect of multiple intravenous injections of butaphosphan and cyanocobalamin on the metabolism of periparturient dairy cows. J. Dairy Sci. 93:4155-4164.

Gaucheron, F. 2005. The minerals of milk. Reprod. Nutr. Dev. 45:473-483.

Greenlee, M., C. S. Wingo, A. A. McDonough, J. H. Youn, and B. C. Kone. 2009. Narrative review: Evolving concepts in potassium homeostasis and hypokalemia. Ann. Intern. Med. 150:619-625.

Grünberg, W., D. E. Morin, J. K. Drackley, and P. D. Constable. 2006. Effect of rapid intravenous administration of $50 \%$ dextrose solution on phosphorus homeostasis in postparturient dairy cows. J. Vet. Intern. Med. 20:1471-1478.

Holt, C., D. G. Dalgleish, and R. Jenness. 1981. Calculation of the ion equilibria in milk diffusate and comparison with experiment. Anal. Biochem. 113:154-163.

Holtenhuis, K., and K. Dahlborn. 1990. Water and sodium movements across the ruminal epithelium in fed and food-deprived sheep. Exp. Physiol. 75:57-67.

Hörügel, U., and M. Fürll. 1998. Investigations on early diagnosis of disposition to parturient paresis. Prakt. Tierarzt. Coll. Vet. 23:86-92

Johnson, P. J., T. E. Goetz, J. H. Foreman, J. H. Foreman, R. S. Vogel, W. E. Hoffman, and G. J. Baker. 1991. Effect of whole-body potassium depletion on plasma erythrocyte, and middle gluteal muscle potassium concentration of healthy adult horses. Am. J. Vet. Res. 52:1676-1683.

Kalaitzakis, E., N. Panousis, N. Roubies, E. Kaldrymidou, and H. Karatzias. 2010. Macromineral status of dairy cows with concurrent left abomasal displacement and fatty liver. N. Z. Vet. J. 58:307-311.

Kowalczyk, D. F., and G. P. Mayer. 1972. Cation concentration in skeletal muscle of paretic and nonparetic cows. Am. J. Vet. Res. 33:751-757.

Leonhard-Marek, S., F. Stumpff, and H. Martens. 2010. Transport of cations and anions across forestomach epithelia: Conclusions from in vitro studies. Animal 4:1037-1056.

Neff, A. W., N. D. Connor, and H. S. Bryan. 1960. Studies on $9 \alpha$-fluroprednisolone acetate, a new synthetic corticosteroid for the treatment of bovine ketosis. J. Dairy Sci. 43:553-562.

Neiger, R. D., and W. A. Hagemoser. 1985. Renal percent clearance ratios in cattle. Vet. Clin. Pathol. 14:31-35.

NRC. 2001. Nutrient Requirements of Dairy Cattle. 7th rev. ed. National Academy Press, Washington, DC.

Oshima, M., and H. Fuse. 1977. Inverse relationship between the electrolyte concentration and the content of fat, protein, and lactose in the normal milks of individual cows from the same herd. J. Dairy Res. 44:347-350.

Peek, S. F., T. J. Divers, C. Guard, A. Rath, and W. C. Rebhun. 2000. Hypokalemia, muscle weakness, and recumbency in dairy cattle. Vet. Ther. 1:235-244.

Pradhan, K., and R. W. Hemken. 1968. Potassium depletion in lactating dairy cows. J. Dairy Sci. 51:1377-1381.

Radostits, O. M., C. C. Gay, K. W. Hinchcliff, and P. D. Constable. 2007. Veterinary Medicine: A Textbook of the Diseases of Cattle, Sheep, Pigs, Goats, and Horses. 10th ed. W. B. Saunders Co., London, UK.

Sasser, L. B., G. M. Ward, and J. E. Johnson. 1966. Variations in potassium concentration of cow's milk. J. Dairy Sci. 49:893-894.

Sattler, N., G. Fecteau, Y. Couture, and A. Tremblay. 2001. Determination of the potassium balances in dairy cows and the examination of daily and lactation period-associated variations. Can. Vet. J. $42: 107-115$. 
Sattler, N., G. Fecteau, C. Girard, and Y. Couture. 1998. Description of 14 cases of bovine hypokalemia syndrome. Vet. Rec. 143:503507.

Schulze, B. 2009. Ex vivo changes of metabolic profile parameters in bovine blood. A contribution to the development of quality standards for blood sampling in cattle. PhD Thesis. Freie Universität Berlin, Germany.

Scott, D. 1967. The effects of potassium supplements upon the absorption of potassium and sodium from sheep rumen. Q. J. Exp. Physiol. 52:382-391.

Shalit, U., E. Maltz, N. Silanikove, and A. Berman. 1991. Water, sodium, potassium, and chloride metabolism of dairy cows at the onset of lactation in hot weather. J. Dairy Sci. 74:1874-1883.

Sielman, E. S., R. W. Sweeney, R. H. Whitlock, and R. Y. Reams, 1997. Hypokalemia syndrome in dairy cows: 10 cases (1992-1996). J. Am. Vet. Med. Assoc. 210:240-243.

Sim, D. W., and G. H. Wellington. 1976. Potassium concentration in bovine muscle as influenced by carcass location, breed, sex, energy intake, age, and shrunk body weight. J. Anim. Sci. 42:84-91.

Smith, G. W., P. D. Constable, and D. E. Morin. 2001. Ability of hematologic and serum biochemical variables to differentiate gram- negative and gram-positive mastitis in dairy cows. J. Vet. Intern. Med. 15:394-400.

Stankovic, A. K., and S. Smith. 2004. Elevated serum potassium values. The role of preanalytic variables. Am. J. Clin. Pathol 121(Suppl.):S105-S112.

Svendsen, P. 1969. Evidence of a potassium shift from the extracellular to the intracellular fluid space during metabolic alkalosis in cattle. Nord. Vet. Med. 21:660-663.

Vestweber, J. G. E., F. K. Al-Ani, and D. E. Johnson. 1989. Udder edema in cattle: Effects of diuretics (furosemide, hydrochlorothiazide, acetazolamide, and 50\% dextrose) on serum and urine electrolytes. Am. J. Vet. Res. 50:1323-1328.

Weiss, W. P. 2004. Macromineral digestion by lactating dairy cows: Factors affecting digestibility of magnesium. J. Dairy Sci $87: 2167-2171$.

Wittek, T., P. D. Constable, and D. E. Morin. 2005. Abomasal impaction in Holstein-Friesian cows: 80 cases (1980-2003). J. Am. Vet. Med. Assoc. 227:287-291. 